\title{
Diagnosis and treatment of congenital nasal glioma
}

\author{
Maria Baldovin, ${ }^{1}$ Athanasios Saratziotis @ ${ }^{2}$ Sara Munari, ${ }^{3}$ Enzo Emanuelli ${ }^{1}$
}

${ }^{1}$ Department of Neuorosciences, University of Padova Faculty of Medicine and Surgery, Padova, Veneto, Italy

${ }^{2}$ Otolaryngology-Head and Neck Surgery, General University Hospital of Larissa, Larissa, Greece

${ }^{3}$ Department of Neuroscience, University of Padova, Padova, Veneto, Italy

\section{Correspondence to} Dr Athanasios Saratziotis; asaratziotis@gmail.com

Accepted 29 March 2021

\section{DESCRIPTION}

From the first days of life, a female newborn suffered from nasal congestion and a runny nose. The first MRI, at 42 days of life, revealed a solid and expansive mass of $1 \mathrm{~cm}$ in the left nasal fossa. The radiological examination repeated at 4 months of life showed an increase in volume, up to $2 \mathrm{~cm}$ (shown in figure 1A,B). The nasal lesion was characterised by a thin capsule and dense content, without pathologic contrast enhancement. Physical examination revealed a suboccluding mass, covered by intact mucosa. An endoscopic approach was indicated to remove the lesion. Pathological examination revealed neuroglial tissue with neurons and gangliar cells, accompanied by connective tissue with numerous calcifications and psammomatous bodies. Immunohistochemistry (epithelial membrane antigen, neuronal nuclear antigen, neurofilaments, glial fibrillar acidic protein, synaptophysin) supported the diagnosis of nasal glial heterotopia (NGH). The postoperative endoscopic examination at 2 months showed complete healing of the mucosa and no signs of recurrence, confirmed by a new MRI.

$\mathrm{NGH}$, also called nasal glioma, neuroglioma, encephaloma or sequestered encephalocele, is a rare congenital head and neck mass that consists of dysplastic neuroglial tissue and fibrovascular tissue covered by epithelium. Recently, a combination of glial and meningothelial cells was described by Shauer et al. ${ }^{1}$ In about $30 \%$ of cases, it presents intranasally, like the case reported herein, in 60\% as an extranasal type in subcutaneous tissues and in $10 \%$ as a mixed form. Ginat has described a group of lesions within the congenital nasal anomalies, which primarily appear as a mass. ${ }^{2}$ Our case of intranasal glioma could be easily confused with a

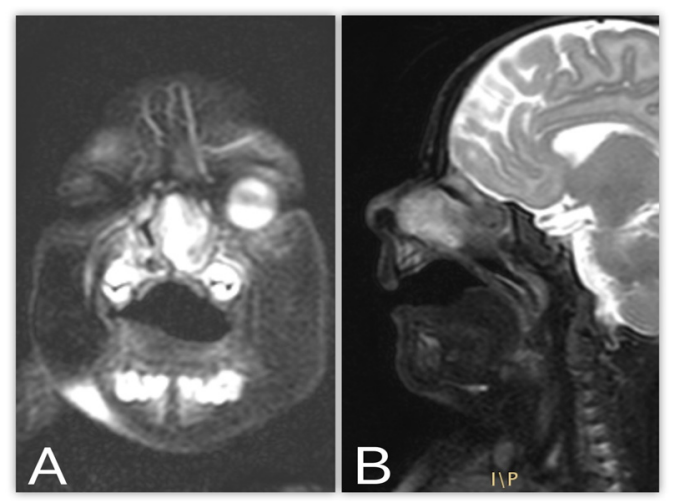

Figure 1 Coronal (A) and sagittal (B) T2 weighted MRI (A) show a solid, expansive mass of $20 \times 21 \mathrm{~mm}$ in the left nasal fossa. nasolacrimal mucocele, as the radiologist suggested, or a cephalocele.

Nasolacrimal mucoceles are characterised by a cystic mass at the medial canthus with dilatation of the nasolacrimal duct that can, rarely, extend into the nasal cavity.

Congenital cephaloceles usually occur at the site where gaps permit the outward herniation of cerebrospinal fluid (CSF) alone (meningocele) or CSF and gliotic brain tissue (meningoencephalocele); MRI demonstrates continuity of the mass with the intracranial compartment and helps to characterise the contents.

The following conditions are included in differential diagnosis of extranasal form: congenital germline fusion cysts, nasal hamartomas and cutaneous heterotopic meningeal nodules.

Radiological evaluation with CT or MRI has an important role during both preoperative and postoperative phases. ${ }^{3}$ First, imaging can show an eventual fibrous stalk (27\% of cases), which represents the connection between the NGH and the dura; that is the reason why NGH and cephaloceles are often considered as two aspects of the same spectrum. ${ }^{4}$ Postoperative radiological follow-up is fundamental because the recurrence rate has been reported as $4 \%-10 \%{ }^{5}$

NGH is treated by surgical resection because of the increasing volume of the mass and the risk of infection. Craniotomy was more frequently used in the past but is now indicated only for intracranial extension. ${ }^{6}$ For the intranasal type, endoscopic surgery represents a safe and effective technique, providing excellent results on the mucosa without recurrence in very young patients.

\section{Learning points}

Intranasal nasal glial (NG) $(30 \%)$ can be confused with nasolacrimal mucocele or cephalocele. Congenital germline fusion cysts and hamartomas seem extranasal form of NG $(60 \%)$.

- Clinic and imaging are fundamental for differential diagnosis of any congenital nasal mass. Because of its rarity, the diagnosis and the treatment represent a change since the age of the little patients who often have other pathologies or malformations associated.

- The therapy for NG is surgical resection because of the progressive increasing volume of the mass. In particular, the intranasal type is mainly resected using endoscopic surgery with successful results. 
Acknowledgements Department of Pediatric Surgery of University Hospital of Padova.

Contributors MB contributed to conception, design acquisition of data drafting the work and final approval of the version to be published. AS contributed to conception, design acquisition of data drafting the work and final approval of the version to be published. SM contributed to conception, design acquisition of data drafting the work and final approval of the version to be published. EE contributed to conception, design acquisition of data drafting the work and final approval of the version to be published.

Funding The authors have not declared a specific grant for this research from any funding agency in the public, commercial or not-for-profit sectors.

Competing interests None declared.

Patient consent for publication Parental/guardian consent obtained.

Provenance and peer review Not commissioned; externally peer reviewed.
ORCID ID

Athanasios Saratziotis http://orcid.org/0000-0002-2393-4012

\section{REFERENCES}

1 Schauer A, Harvey NT, Vijayasekaran S, et al. Unusual case of combined Gliomeningeal heterotopia on the nose of an infant. Am J Dermatopathol 2018;40:515-8.

2 Ginat DT, Robson CD. Diagnostic imaging features of congenital nose and nasal cavity lesions. Clin Neuroradiol 2015;25:3-11.

3 Maharaj S. Pediatric nasal glial heterotopia. Ear Nose Throat J 2020:23:145561320950496.

4 Bonne N-X, Zago S, Hosana G, et al. Endonasal endoscopic approach for removal of intranasal nasal glial heterotopias. Rhinology 2012;50:211-7.

5 Yan Y-Y, Zhou Z-Y, Bi J, et al. Nasal glial heterotopia in children: two case reports and literature review. Int J Pediatr Otorhinolaryngol 2020;129:109728.

6 Adil E, Robson C, Perez-Atayde A, et al. Congenital nasal neuroglial heterotopia and encephaloceles: an update on current evaluation and management. Laryngoscope 2016;126:2161-7.

Copyright 2021 BMJ Publishing Group. All rights reserved. For permission to reuse any of this content visit

https://www.bmj.com/company/products-services/rights-and-licensing/permissions/

BMJ Case Report Fellows may re-use this article for personal use and teaching without any further permission.

Become a Fellow of BMJ Case Reports today and you can:

- Submit as many cases as you like

- Enjoy fast sympathetic peer review and rapid publication of accepted articles

- Access all the published articles

Re-use any of the published material for personal use and teaching without further permission

Customer Service

If you have any further queries about your subscription, please contact our customer services team on +44 (0) 2071111105 or via email at support@bmj.com.

Visit casereports.bmj.com for more articles like this and to become a Fellow 